Gut, 1963, 4, 217

\title{
Pancreatic replacement therapy in the treatment of pancreatic steatorrhoea
}

\author{
I. N. MARKS 1 , S. BANK ${ }^{2}$, AND EVELYN M. AIRTH \\ From the Gastrointestinal and Diagnostic Radioisotope Services, Groote Schuur \\ Hospital, and the Department of Medicine, University of Cape Town
}

EDITORIAL SYNOPSIS The effect of a whole pancreas preparation (Viokase) has been investigated in 11 patients with pancreatic steatorrhoea and in five patients with steatorrhoea due to other causes. The appearance of the stool, faecal fat, and stool and blood radioactivity after a given dose of $I^{\mathbf{1 3 1}}$ triolein (Raolein) were employed in assessing the response to Viokase therapy. Pancreatic steatorrhoea was considerably improved in the majority of patients, and showed some improvement in the remainder. Viokase appeared to be of limited value in the treatment of post-gastrectomy steatorrhoea, and failed to influence fat absorption in steatorrhoea due to disorder of the small intestine.

Patients with gross pancreatic insufficiency present several problems in management. The staggered onset of chronic alcoholism in a usually inadequate personality, severe and often intractable pancreatic pain leading to drug addiction, and progressive pancreatic insufficiency causing diabetes and steatorrhoea frequently produce a pathetic individual bereft of spouse, job, and self respect. Severe pain is usually the most arresting symptom of advanced pancreatitis but in others diabetes and steatorrhoea constitute the major clinical features of the disease. Indeed steatorrhoea may be the presenting feature in some diabetic subjects with pancreatic insufficiency.

Pancreatic steatorrhoea may be a most distressing condition. The fat content of the stools often exceeds that found in other types of steatorrhoea and frequently results in unusually buoyant and offensive stools. The persistent loss of large amounts of fat and protein in the stool contributes to the profound weight loss sometimes found in patients with chronic pancreatitis. In addition, the buoyancy of the stools may cause difficulty in flushing them from the lavatory pan and this, together with the offensive nature of the stools, may be embarrassing socially.

Substitution therapy with pancreatic extract has been employed in the treatment of pancreatic steatorrhoea for many years. Disappointing results with standard preparations led many workers to question the efficacy of such treatment and prompted

1Part-time C.S.I.R. senior bursar.

${ }^{2}$ Ben May research fellow in gastroenterology. a search for more potent preparations. A stable preparation of activated whole raw pancreas (Viokase $^{3}$ ) has recently been shown to be remarkably potent in enhancing the absorption of fat and nitrogen in patients with exocrine insufficiency of the pancreas (Longmire, Jordan, and Briggs, 1956; Jordan and Grossman, 1957; Jordan and Grossman, 1959; Polachek and Williard, 1960). The administration of Viokase at hourly intervals has been shown to be more effective in reducing faecal fat than when given in three doses with meals (Jordan and Grossman, 1959).

\section{MATERIALS AND METHODS}

Sixteen patients, 11 with pancreatic steatorrhoea and five with non-pancreatic steatorrhoea, with unequivocal laboratory evidence of steatorrhoea were studied. The pancreatic steatorrhoea group (Table I) includes six patients in whom operative procedures have been carried out. These include a total pancreaticoduodenectomy, subtotal gastrectomy and splenectomy (case 1), a Whipple's procedure (case 5), a distal pancreatectomy and implanting the tail of the pancreas into the jejunum (case 10), drainage of a pancreatic cyst into the stomach (case 4), and sphincterotomy and T-tube drainage of the common bile duct (cases 2 and 6). Five patients were not operated upon. Pancreatic function tests utilizing secretin and pancreozymin stimulation (Marks and Tompsett, 1958) were carried out in 10 of the 11 patients; a grossly diminished bicarbonate and amylase content of the duodenal aspirate was noted in all patients tested. The remaining patient (case 5) had had a Whipple's

'Prepared by Viobin Corp., Monticello, Ill., U.S.A. 
procedure for chronic pancreatitis with calcification and diabetes. Pancreatic calcification was present in nine of the 11 patients. Seven of the 11 patients were known to have diabetes, and a further three were found to have diabetes by means of the glucose tolerance test; steatorrhoea unassociated with diabetes was present in only one (case 2), a patient with fibrocystic disease of the pancreas, but glucose tolerance was clearly abnormal. Steatorrhoea was a major clinical feature in eight of the patients, one of whom had not considered his stools particularly abnormal.

The non-pancreatic steatorrhoea group comprised two post-gastrectomy subjects and three patients with malabsorption associated with disease of the small intestine and normal pancreatic function as measured by the pancreatic function test. The glucose tolerance test did not suggest a diabetic or pre-diabetic state in the two post-gastrectomy subjects. Steatorrhoea was a major feature in all five patients.

In most cases studies consisted of two five-day experimental periods. No replacement therapy was given during one of the periods, and Viokase, two tablets every hour from 7 a.m. to 9 p.m., was given throughout the other. The majority of the patients received a standard hospital diet containing 75 to $150 \mathrm{~g}$. fat per day.

Fat absorption was measured by both the labelled fat and faecal fat methods in many patients and by only one of these techniques in the remainder. Repeat tests after an interval of about one year were carried out in two patients.

$I^{131}$ triolein (Raolein) was fed to the fasting patient, and absorption assessed by measuring whole blood radioactivity levels at four and six hours, and by measuring the radioactivity of the stools collected for five days following the administration of Raolein. The patients were not prepared with Lugol's solution (Grossman and Jordan, 1958). The Raolein was prepared in a special base stable at room temperature to prevent leakage from the gelatin capsule during transit from the United States to South Africa. A peak level of whole blood radioactivity of less than $7 \%$ and of stool radioactivity greater than $7 \%$ was regarded as evidence of abnormal fat absorption.

The fat content of the five-day collection was then measured by the method of van de Kamer, Huinink, and Weijers (1949) after an appropriate interval to allow for decay of stool radioactivity. A stool fat content greater than $7 \mathrm{~g}$. per day indicated abnormal fat absorption.

The effect of Viokase on protein absorption was studied by means of nitrogen balances in the one patient in whom total pancreatectomy had been carried out (case 1). The balances were carried out over two four-day experimental periods. The nitrogen content of the diet was estimated by a dietitian, and aliquots of homogenized four-day stool collections analysed by the Kjeldahl method for faecal nitrogen.

\section{CLINICAL RESULTS}

PANCREATIC STEATORRHOEA Steatorrhoea was the presenting symptom in five patients, and a major clinical feature in a further two patients (Table I). Direct questioning elicited a story suggestive of steatorrhoea in the remaining four patients; the steatorrhoea was, in fact, fairly gross in three of these four. The administration of Viokase was associated with a striking improvement in the nature of the stools in eight patients, and was of some value in the remaining three (cases 1,3 , and 9). The improvement was characterized by the stools becoming darker in appearance and less bulky, buoyant, greasy, and offensive in nature. The role of Viokase in improving the general condition of the patient was found difficult to assess because of the pain and diabetes so frequently present in patients with pancreatic steatorrhoea, but a striking gain in weight in two patients (cases 2 and 4 ) was considered to be due largely to long-term administration of

TABLE I

Clinical Data IN 11 PATIENTS WITH PANCREATIC STEATORRHOEA

\begin{tabular}{|c|c|c|c|c|c|c|c|c|c|c|c|}
\hline \multicolumn{2}{|c|}{$\begin{array}{l}\text { Case } \\
\text { No. }\end{array}$} & $\operatorname{sex}$ & Age & Aetiology & Pancreatic Surgery & $\begin{array}{l}\text { Abnormal } \\
\text { Pancreatic } \\
\text { Function } \\
\text { Test }\end{array}$ & Calcification & Diabetes & Steatorrhoea & $\begin{array}{l}\text { Pancreatic } \\
\text { Pain }\end{array}$ & Jaundice \\
\hline 1 & $\mathbf{E}$ & $\mathbf{M}$ & 36 & EtOH & Total pancreatectomy & + & + & + & + & -3 & - \\
\hline 2 & $\mathbf{E}$ & $\mathbf{M}$ & 46 & $?$ & Sphincterotomy & + & + & +1 & + & $\pm^{3}$ & - \\
\hline 3 & $\mathbf{E}$ & $\mathbf{M}$ & 22 & Fibrocystic & Nil & + & - & $\begin{array}{l}\text { Abnormal } \\
\text { glucose } \\
\text { tolerance }\end{array}$ & + & \pm & - \\
\hline 4 & $\mathbf{E}$ & $\mathbf{F}$ & 44 & EtOH & Cystgastrostomy & + & + & + & + & -3 & - \\
\hline 5 & $\mathbf{E}$ & $\mathbf{M}$ & 46 & EtOH & Whipple's operation & & + & + & + & $\pm^{3}$ & - \\
\hline 6 & $\mathbf{E}$ & $\mathbf{M}$ & 45 & EtOH & $\begin{array}{l}\text { Sphincterotomy } \\
\text { Cyst drained }\end{array}$ & + & + & + & $+^{2}$ & + & + \\
\hline 7 & C & $\mathbf{M}$ & 43 & EtOH & None & + & + & + & + & -3 & - \\
\hline 8 & $\mathbf{C}$ & $\mathbf{M}$ & 33 & EtOH & None & + & + & + & +2 & $\pm^{3}$ & - \\
\hline 9 & C & $\mathbf{M}$ & 33 & EtOH & None & + & + & +1 & $\pm^{2}$ & + & - \\
\hline 10 & $\mathbf{E}$ & $\mathbf{F}$ & 24 & & Distal pancreatectomy & + & - & +1 & + & -3 & - \\
\hline 11 & C & $\mathbf{M}$ & 23 & Nutritional & None & + & + & + & $t^{2}$ & - & - \\
\hline
\end{tabular}

Diabetes found on routine testing with glucose tolerance test; steatorrhoea preceded onset of diabetic glucose tolerance by two years in case 2. History of steatorrhoea elicited on direct questioning only. Past history of typical pancreatic pain.

$\mathbf{E}=$ European
EtOH $=$ alcohol 
Viokase. The gross steatorrhoea in one of these patients was associated with colicky abdominal pains; the latter disappeared with improvement of the steatorrhoea on Viokase therapy.

NON-PANCREATIC STEATORRHOEA Only one of the five patients investigated, a post-gastrectomy subject, showed definite improvement while on Viokase (Table III). Some improvement was noted in two patients but the steatorrhoea was unaltered in the remaining two.

\section{RESULTS OF TESTS OF FAT ABSORPTION}

PANCREATIC STEATORRHOEA Data for the stool fat content, stool radioactivity, and blood radioactivity obtained in the patients with pancreatic steatorrhoea are presented in Table II and Figs. 1 and 2. Marked improvement was evident with all the parameters of fat absorption employed in eight of the 11 patients. Clinical improvement was reflected by only the blood radioactivity levels in one of the patients (case 9), and an appreciable, but slight, diminution in faecal fat in another (case 1). The tests showed only minimal improvement in the remaining patient (case 3), the only case of fibrocystic disease of the pancreas in this series, but the character of the stools in this patient appeared less abnormal during treatment with Viokase. Two patients (cases 2 and 4) who required continued Viokase therapy showed clinical improvement in the steatorrhoea while on a smaller dose of Viokase (4 tablets q.d.s.); but biochemical and radioactive studies were not carried out on this dosage schedule.

In general, the quantitative measures of fat absorption paralleled the degree of clinical steatorrhoea, but improvement in the character of the stools while the patients were on Viokase therapy was more adequately reflected by stool radioactivity than by stool fat content in some patients (cases 2 , 4 , and 7).

The results of two four-day nitrogen balance studies carried out in the post-pancreatectomy subject (case 1) before and during Viokase administration is shown in Table IV. Viokase therapy was associated with a slight improvement in nitrogen retention, and the percentage absorption increased from $60 \cdot 6$ to $67 \cdot 4$.

TABLE II

CLINICAL AND LABORATORY DATA ON EFFECT OF VIOKASE IN PANCREATIC STEATORRHOEA

\begin{tabular}{|c|c|c|c|c|c|c|c|c|c|c|c|}
\hline \multirow{3}{*}{$\begin{array}{l}\text { Case } \\
\text { No. }\end{array}$} & \multicolumn{3}{|c|}{ Clinical Steatorrhoea } & \multicolumn{4}{|l|}{ Stools } & \multicolumn{4}{|c|}{ Blood I ${ }^{131}$ Level ( $\%$ dose $)$} \\
\hline & \multirow[t]{2}{*}{ Before } & \multirow[t]{2}{*}{ After } & \multirow[t]{2}{*}{ Improved } & \multicolumn{2}{|c|}{ Weight (g. per day) } & \multicolumn{2}{|c|}{$I^{131}$ Raolein (\% dose) } & \multicolumn{2}{|l|}{ Before } & \multicolumn{2}{|l|}{ After } \\
\hline & & & & Before & After & Before & After & 4 Hours & 6 Hours & 4 Hours & 6 Hours \\
\hline 1 & + & + & \pm & 82.5 & 68.7 & & & & & & \\
\hline 2 & + & - & + & 49.0 & 26.0 & $41 \cdot 8$ & $4 \cdot 0$ & 1.2 & 1.5 & $4 \cdot 3$ & $3 \cdot 1$ \\
\hline \multirow[t]{2}{*}{3} & + & + & \pm & & & $29 \cdot 1$ & $26 \cdot 6$ & 1.4 & 2.0 & 9.8 & 7.4 \\
\hline & + & + & \pm & $18 \cdot 3$ & 17.8 & 38.9 & 35.9 & 3.5 & 6.2 & $2 \cdot 3$ & $2 \cdot 6$ \\
\hline \multirow[t]{2}{*}{4} & + & - & + & & & 30.9 & $8 \cdot 1$ & 3.8 & 5.4 & 14.0 & $10 \cdot 4$ \\
\hline & + & - & + & $19 \cdot 3$ & $8 \cdot 2$ & $27 \cdot 3$ & 3.7 & 3.2 & 4.8 & $13 \cdot 2$ & 9.6 \\
\hline 5 & + & \pm & + & 29.9 & 12.5 & $37 \cdot 7$ & $27 \cdot 8$ & & & & \\
\hline 6 & + & - & + & & & 33.8 & 5.0 & & & & \\
\hline 7 & + & - & + & 26.9 & 10.9 & 14.5 & 4.7 & & & & \\
\hline 8 & + & \pm & + & $64 \cdot 4$ & $26 \cdot 1$ & & & & & & \\
\hline 9 & + & \pm & \pm & 10.2 & $9 \cdot 3$ & 8.2 & 17.5 & 1.8 & 4.2 & 15.6 & $12 \cdot 7$ \\
\hline 10 & + & - & + & $9 \cdot 3$ & $4 \cdot 2$ & $37 \cdot 4$ & $13 \cdot 1$ & & & & \\
\hline 11 & \pm & - & + & 28.9 & $7 \cdot 2$ & 20.0 & 5.0 & & & & \\
\hline
\end{tabular}

TABLE III

CLINICAL AND LABORATORY DATA ON EFFECT OF VIOKASE ON NON-PANCREATIC STEATORRHOEA

\begin{tabular}{|c|c|c|c|c|c|c|c|c|c|c|c|c|c|}
\hline \multirow{3}{*}{$\begin{array}{l}\text { Case } \\
\text { No. }\end{array}$} & \multirow[t]{3}{*}{ Aetiology } & \multirow{3}{*}{$\begin{array}{l}\text { Abnormal } \\
\text { Pancreatic } \\
\text { Function } \\
\text { Test }\end{array}$} & \multicolumn{3}{|c|}{ Clinical Steatorrhoea } & \multicolumn{4}{|l|}{ Stool } & \multicolumn{4}{|c|}{ Blood I Is1 Level (\% dose) } \\
\hline & & & \multirow[t]{2}{*}{ Before } & \multirow[t]{2}{*}{ After } & \multirow{2}{*}{$\begin{array}{l}\text { Im- } \\
\text { proved }\end{array}$} & \multicolumn{2}{|c|}{$\begin{array}{l}\text { Weight } \\
\text { (g.per day) }\end{array}$} & \multicolumn{2}{|c|}{$\begin{array}{l}I^{131} \text { Raolein } \\
(\% \text { dose })\end{array}$} & \multicolumn{2}{|l|}{ Before } & \multicolumn{2}{|l|}{ After } \\
\hline & & & & & & Before & After & Before & After & 4 Hours & 6 Hours & 4 Hours & 6 Hours \\
\hline $\begin{array}{l}12 \\
13 \\
14 \\
15\end{array}$ & $\begin{array}{l}\text { Post-gastrectomy } \\
\text { Post-gastrectomy } \\
\text { Stagnant loop } \\
\text { Idiopathic }\end{array}$ & - & $\begin{array}{l}+ \\
+ \\
+\end{array}$ & $\begin{array}{l}+ \\
\pm \\
+\end{array}$ & $\begin{array}{l} \pm \\
+ \\
\pm\end{array}$ & $\begin{array}{l}13.6 \\
16.2 \\
12.2\end{array}$ & $\begin{array}{r}9 \cdot 3 \\
13.8 \\
11.7\end{array}$ & $11 \cdot 6$ & $2 \cdot 2$ & & & & \\
\hline 16 & $\begin{array}{l}\text { steatorrhoea } \\
\text { Mastocytosis }\end{array}$ & - & $\begin{array}{l}+ \\
+\end{array}$ & $\begin{array}{l}+ \\
+\end{array}$ & $\overline{-}$ & $\begin{array}{l}16 \cdot 5 \\
36 \cdot 5\end{array}$ & $\begin{array}{l}10 \cdot 6 \\
40 \cdot 0\end{array}$ & $\begin{array}{l}11 \cdot 2 \\
34 \cdot 5\end{array}$ & $\begin{array}{l}14 \cdot 1 \\
19 \cdot 6\end{array}$ & $\begin{array}{l}2 \cdot 2 \\
2 \cdot 1\end{array}$ & $\begin{array}{l}2.0 \\
4.4\end{array}$ & $\begin{array}{r}5 \cdot 4 \\
11 \cdot 1\end{array}$ & $\begin{array}{r}6.7 \\
11.9\end{array}$ \\
\hline
\end{tabular}


I. N. Marks, S. Bank, and Evelyn M. Airth
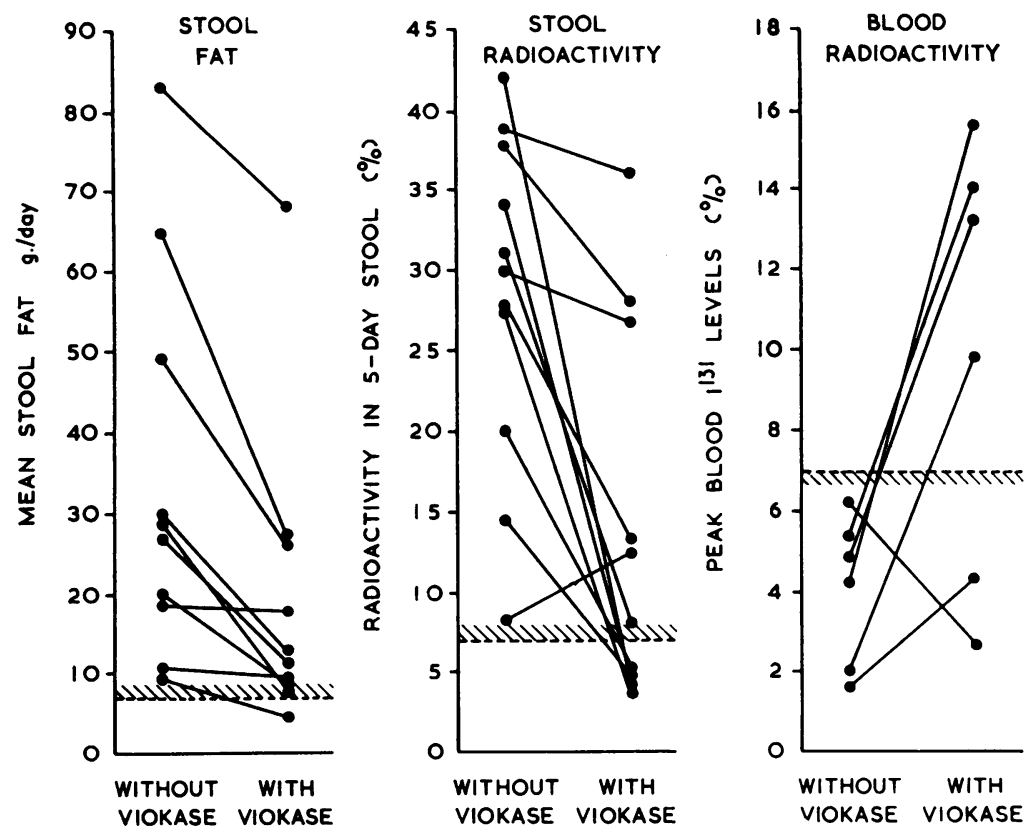

FIG. 1. The effect of Viokase on pancreatic steatorrhoea. Dotted line represents upper limit of normal faecal fat and stool radioactivity and lower limit of blood radioactivity.

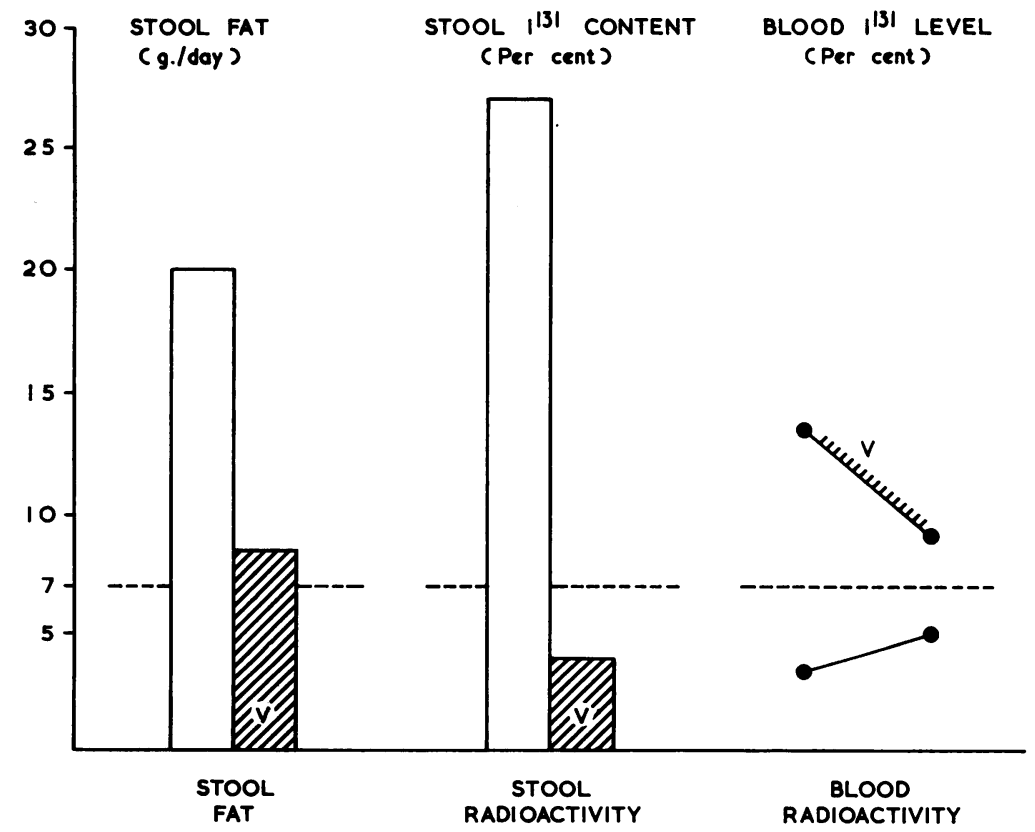

FIG. 2. The effect of Viokase on pancreatic steatorrhoea in case 4. Shaded area represents the response to Viokase $(\mathrm{V})$. 
TABLE IV

EFFECT OF VIOKASE ON NITROGEN ABSORPTION IN PATIENT WITH TOTAL PANCREATICODUODENECTOMY

\begin{tabular}{lcc} 
Case 1 & $\begin{array}{l}\text { Four-day Balance } \\
\text { (g. nitrogen per day) }\end{array}$ & $\begin{array}{l}\text { Four-day Balance with } \\
\text { Viokase }(g . \text { nitrogen per } \\
\text { day) }\end{array}$ \\
\hline Intake & 34.63 & 33.63 \\
Stool & 13.65 & 10.96 \\
Urine & 7.76 & 7.84 \\
Absorption & $+20.98=60.6 \%$ & $+22.67=67.4 \%$ \\
Retention & +13.22 & +14.83
\end{tabular}

NON-PANCREATIC STEATORRHOEA The results in this group are tabulated in Table III. A slight reduction in faecal fat was noted in three patients, one of whom showed a striking improvement in stool radioactivity (case 13) and a good clinical response to Viokase. One of the patients in whom both the appearance and the faecal fat content of the stools remained unaltered showed improved blood radioactivity levels.

\section{DISCUSSION}

The results of our study confirms the observations of previous workers regarding the efficacy of pancreatic replacement therapy in improving fat absorption and diminishing the degree of steatorrhoea in patients with pancreatic steatorrhoea (Longmire et al., 1956; Jordan and Grossman, 1957; Jordan and Grossman, 1959; Polachek and Williard, 1960). There was a marked improvement in the character of the stools in eight of the 11 patients investigated, and in many of these the stools appeared completely normal while they were receiving Viokase. This improvement was reflected by improved fat absorption as measured by faecal fat and stool and plasma radioactivity following a known dose of $\mathrm{I}^{131}$ triolein (Raolein) and, in the one patient tested, by enhanced nitrogen absorption. Two of the three patients who showed only a moderate clinical response to Viokase had little or no pancreatic function; one had had a total pancreaticoduodenectomy, and the other was a 24-year-old subject with fibrocystic disease of the pancreas with grossly defective pancreatic function as measured by the response to secretin and pancreozymin stimulation. It is conceivable that a larger dose of Viokase may have further improved fat absorption in these two patients. The possibility of associated small bowel disorder could not be excluded in the remaining patient.

Most patients agreed that the improvement in the character of the stools more than justified the inconvenience of long-term Viokase therapy. Pan- creatic steatorrhoea is not necessarily persistent or progressive, however, and it was found necessary to determine the effect of Viokase withdrawal after a few weeks to determine whether spontaneous improvement had not rendered the replacement therapy redundant. Four of the patients in the present series have found it necessary to remain on Viokase for over 18 months (cases 2, 3, 5, and 10).

The data in patients with post-gastrectomy steatorrhoea suggest that Viokase may have a limited place in the treatment of such patients. Inadequate stimulation of the pancreas following a meal, and impaired mixing of the pancreatic juice with the food due to a transient hold-up of the bile and pancreatic secretion in the afferent loop, have been cited as possible causes of post-gastrectomy steatorrhoea (Shingleton, Isley, Floyd, Sanders, Baylin, Postlethwait, and Ruffin, 1957; Schwartz, Bodansky, and Randall, 1956; Johnson, Horswell, Tyor, Owen, and Ruffin, 1961) and would appear to support the rationale of a therapeutic trial of pancreatic replacement therapy in this condition (Johnson et al., 1961; Rekers, Pack, and Rhoads, 1943; Everson, 1952).

The difference in response to pancreatic replacement therapy between patients with pancreatic steatorrhoea and small bowel malabsorption has been previously noted and a simple test based on this fact has been advocated in differentiating the two conditions (Polachek and Williard, 1960). Our experience suggests that the response to Viokase, particularly as measured by changes in blood radioactivity levels, is no more than a useful screening test, and that it cannot be relied upon to replace the more conventional diagnostic tests of pancreatic and small bowel disorder.

This study was supported by the South African Council of Scientific and Industrial Research and by the Ben May Gastroenterology Research Fund.

We wish to thank Professor J. E. Kench of the Department of Chemical Pathology for carrying out the stool faecal fat determinations, and Dr. J. G. Burger, Superintendent of Groote Schuur Hospital, for permission to publish.

Supplies of Viokase were made available to us by the Viobin Corporation, Monticello, Ill., U.S.A.

\section{REFERENCES}

Everson, T. C. (1952). Collective review. Nutrition following total gastrectomy, with particular reference to fat and protein assimilation. Int. Abstr. Surg., 95, 209-230.

Grossman, M. I., and Jordan, P. H, Jr. (1958). The radio-iodinated triolein test for steatorrhoea. Gastroenterology, 34, 892-900.

Johnson, J. H., Horswell, R. R., Tyor, M. P., Owen, E. E., and Ruffin, J. M. (1961). Effect of intestinal hormones on $I^{131}$ triolein absorption in subtotal gastrectomy patients and intubated normal persons. Ibid., 41, 215-219. 
Jordan, P. H. Jr., and Grossman, M. I. (1957). Pancreaticoduodenectomy for chronic relapsing pancreatitis. Metabolic effects created by total and subtotal ablations. A.M.A. Arch. Surg., 74, 871-880.

_substitution therapy in pancreatic insufficiency.Gastroenterology, $36,447-451$.

Longmire, W. P. Jr., Jordan, P. H. Jr., and Briggs, J. D. (1956). Experience with resection of the pancreas in the treatment of chronic relapsing pancreatitis. Ann. Surg., 144, 681-695.

Marks, I. N., and Tompsett, S. L. (1958). The diagnosis of pancreatic disease, with special reference to a test of pancreatic secretion utilizing both secretin and pancreozymin stimulation. Quart. J. Med., 27, 431-461.

Polachek, A. A., and Williard, R. F. (1960). I $^{131}$-labelled fat and pancreatin as a differential absorption test in patients with steatorrhoea. Ann. intern Med., 52, 1195-1200.
Rekers, P. E., Pack, G. T., and Rhoads, C. P. (1943). Metabolic studies in patients with cancer of the gastro-intestinal tract; VI. Disorders in alimentary digestion and absorption in patients who have undergone total gastrectomy for carcinoma of stomach. Surgery, 14, 197-215.

Schwartz, M. K., Bodansky, O., and Randall, H. T. (1956). Metabolism in surgical patients. III. Effect of drugs and dietary procedures on fat and nitrogen metabolism in totally gastrectomized patients. Ibid., 40, 671-677.

Shingleton, W. W., Isley, J. K., Floyd, R. D., Sanders, A. P., Baylin, G. J., Postlethwait, R. W., and Ruffin, J. M. (1957). Studies on postgastrectomy steatorrhoea using radioactive triolein and oleic acid. Ibid., 42, 12-21.

van de Kamer, J. H., Huinink, H. ten B., and Weijers, H. A. (1949). Rapid method for the determination of fat in the faeces. $J$. Biol. Chem., 177, 347-355. 